\title{
陸面・河川汇濫モデルによる \\ 洪水影響人口の全球実時間算定システムの構築 \\ DEVELOPMENT OF A GLOBAL FLOOD AFFECTED POPULATION REAL-TIME CALCULATION SYSTEM WITH A LAND SURFACE-FLOOD INUNDATION MODEL
}

\author{
鳩野 美佐子 ${ }^{1} \cdot$ 芳村 圭 $^{2} \cdot$ 山崎 大 $^{3} \cdot$ 沖 大幹 $^{4}$ \\ Misako HATONO, Kei YOSHIMURA, Dai YAMAZAKI and Taikan OKI \\ ${ }^{1}$ 学生会員 東京大学大学院 工学系研究科社会基盤学専攻（†153-8505 東京都目黒区駒場4-6-1） \\ ${ }^{2}$ 正会員 工博 東京大学准教授 大気海洋研究所（ \\ ${ }^{3}$ 正会員 工博 研究員 University of Bristol, School of Geograph. Sci. (University Road, Bristol BS8 1SS, UK) \\ ${ }^{4}$ 正会員 工博 東京大学教授 生産技術研究所（干153-8505 東京都目黒区駒場4-6-1）
}

\begin{abstract}
Damage caused by floods can sometimes be catastrophic. When focusing on lessening the fatalities/victims, knowledge of a flood even just a day in advance could make a difference. Therefore, this research aims to develop a global real time calculation system for flood affected population. A new river model, CaMa-Flood, is introduced into the framework of Today's Earth, a real time calculation system for various hydrological aspects. Gridded population data was then combined to calculate the number of estimated affected population. Validations for the outputs of this system were conducted using multiple observation data. Comparison with floods in 2013 showed that this system was able to detect the occurrence of floods to a certain degree.
\end{abstract}

Key Words : Flood, real-time calculation, affected people

\section{1.はじめに}

2011 年にタイを襲った洪水では被害を受けた農地は 18,291 km²にのぼり，被害額は約 3.5 兆円と推定されてい る ${ }^{1)}$. 一方日本でも熊本県で起きた平成 24 年 7 月 12 日 熊本広域大水害では 3,422 棟の住家が被害を受け, 被害 額は約 690 億円とされている ${ }^{2)}$. また, 1985 年から 2009 年までの間に洪水は自然災害のうち最も頻繁に起こり

（全体の 40\%），自然災害による被害者の半分以上は 洪水によるとされている ${ }^{3)}$. 気候変動に関する政府間パ ネルによる第 4 次評価報告書 ${ }^{4}$ )では洪水被害は気候変動 によって今後増加すると報告されており，洪水に対する 予測技術の必要性はさらに高まると考えられる.

洪水評価に関してはある特定の地域に着目して行わ れることが多くある.これは洪水評価を行う際に用いる データや条件が地域によって大きく異なるということが 一つの原因として挙げられる. 特定の地域に着目寸るの ではなく全球で洪水評価を行うことにより, データが不 足しがちな発展途上国でもある一定の精度を期待するこ
とができ，より多くの地域における洪水対策に貢献でき ると考えられる. また，それぞれの地域に特化した洪水 評価は重要であるとしたうえで, 全球での統一された洪 水リスクの算定により俯瞰的な視点から洪水を分析する ことが可能と主張する研究 ${ }^{5} や ~$ 複数のモデルを用いて 地球温暖化の影響による洪水影響人口の変化を算定する 研究 のもある. これらのように洪水指標に関する研究は 多くなされているが，それらを全球かつ実時間で算定し ているものは少ない.

洪水を引き起こす天候などの自然的要因は時々刻々 と変化し, 多少の偏りはあるものの空間的に広い範囲で 洪水は起こり得る. 2010 年 6 月にアメリカのミズーリ川 の支流では上流で 6 時間のうちに約 $135 \mathrm{~mm}$ の雨が降 り，峡谷という地理状況により河川流量が激増して洪水 が生じ 7), また, 2010 年 7 月にパキスタンで起こった洪 水では北東部の 3 県で 4 日間のうち $200 \mathrm{~mm}$ 以上の雨が 降った ${ }^{8)}$. このように数時間から数日の間の悪天候によ り洪水が発生することもあり, 時間とともに変化する状 況に対応して洪水の深刻度評価も時々刻々更新されるべ きであると考えられる. さらに, 洪水による被害は発展 
途上国に限らず先進国にももたらされるが, 早期警戒シ ステムによって多くの人的被害が軽減されてきている ${ }^{9}$. これらを考慮し, 本研究では洪水評価の指標の一つと考 えられる洪水影響人口の全球実時間算定システムを構築 した.

\section{2. モデルと手法}

\section{(1) Today' s Earth}

Today's Earth ${ }^{10}$ は陸面水文過程を全球で実時間算定す るシステムである. 入力值としては気象庁の全球数值予 報モデルGSM $の$ Grid Point Value (以下GSM-GPVとする) を用いる. GSM-GPVは6時間毎に84時間先までの予報值 が6時間間隔で計算されている．本研究で用いるGSMGPVは東京大学生産技術研究所喜連川研究所にアーカイ ブされたものを利用した ${ }^{11)}$.これらのうち12時間毎の GSM-GPV を入力值として陸面過程モデル Minimal Advanced Treatments of Surface Interaction and RunOff $(\text { MATSIRO })^{12)}$ に水の安定同位体を組み込んだIsoMATSIRO $^{13)}$, 河川モデルTotal Runoff Integrating Pathways $(\mathrm{TRIP})^{14)}$ が用いられている.

\section{（2）河川モデルの更新}

Today's Earthの従来の河川モデルであるTRIPは解像度 が荒く, 河道網に沿って水輸送が行われるだけである. また，流速は一定であり，現実的な河川網としての精度 は低い，そこで，本研究ではTRIPの代わりにCatchmentbased Macro-scale Floodplain model (CaMa-Flood) ${ }^{15}$ を用い た. 以降CaMa-FloodをToday's Earthに導入したシステム をTE+CaMaと呼ぶこととする. CaMa-Floodは陸面過程モ デルにより計算された流出量を河道網に沿って流下させ る河川モデルである. 既往研究15)に従って本研究では空 間解像度を 0.25 度格子とした. 河川流域は単位集水域一 と分けられ，サブグリッド地形パラメータを用いてサブ グリッドの物理過程として氾濫を表現している．従来の 河川モデルでは，矩形の河道のみが貯水槽として考慮さ れていたが，CaMa-Floodでは河道に加えて汇濫原の貯水 槽が定義されている. また, 従来は流速が一定とされて いたのに対してCaMa-Floodでは拡散波方程式で流速の変 化も表現することが可能となり，より現実的な河道流下 モデルとなっている．河川モデルとしてCaMa-Floodを用 いることにより, 高度化・高解像度化が図られる.

\section{（3）手法の概要}

上記のとおり，Today's Earthの河川モデルを河川汇濫 モデルCaMa-Floodに変更することにより流量や汇濫面積, 水深などを得ることができる. 観測值を用いてこれらの 出力值の検証をおこなったのち，人口データなどを用い て洪水による影響人口の算定を行う。
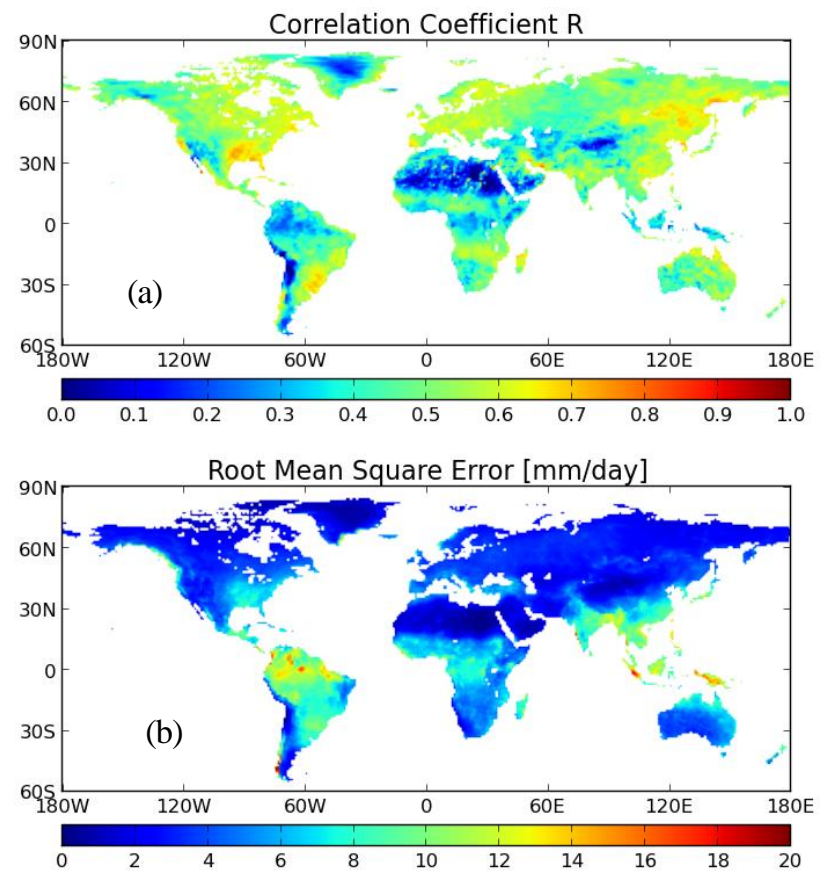

図-1 GPCP と本システムによる降水量の

(a) 相関係数 (b) RMSE

本研究の対象期間は2008年から現在までである．2007年 に気象庁の予報システムに大幅な変更があり, 同条件で 解析ができないと判断したため2008年からとしている. 対象地域は全球であるが，検証はある特定の地域に着目 して行っている. Today's EarthとTE+CaMaによる出力值 はそれぞれ1度格子と0.25度格子である。

\section{3. 結果および検証}

Today's Earthの改良版として新たに加えられるものは 高解像度の河川流量, 河川貯留量, 汇濫原貯留量, 汇濫 面積, 水深などである.これらは1日2回計算されており, 84時間先までの予測值が日単位で提供される.

それぞれのモデルの精度については既往文献(1012)(13)14115) を参照されたい，ここではGSM-GPVによる解析值から 12時間予報值を連続的に用いた場合のモデルの出力値に ついての検証結果を示す。

\section{（1）降水量}

Global Precipitation Climatology Project ${ }^{16)}$ (以下GPCP と する）による空間解像度 1 度, 時間解像度1日のデータを 用いてTE+CaMaによる降水量の検証を2008年から2012 年について行った。 モデルによる降水量の空間解像度は 1度, 時間解像度は6時間のため, 日平均降水量一と変換 した。本システムの目的は洪水評価であるため, 図一 1a, bに陸域のみの相関係数と平均二乗誤差RMSEをそれ ぞれ示す．相関係数は陸域の大部分について95\%有意を 示している. アフリカ大陸北部は特に低い相関を示して 
いるが，これは全体的に降水量が少ない砂漠域であるこ とによると考えられる。ここで検証している降水量は GSM-GPVを1度格子へと変換したものであり，本システ ムの入力值として用いられている。 これまでの研究によ り，観測された降水量を用いると河川流量の再現性が高 くなることが分かっているため ${ }^{15)}$ ，今後，気象庁の予報 システムが改良することにより降水量予測の精度が向上 寸れば，本システムの精度も上がることが期待される.

\section{（2）河川流量}

Global Runoff Data Centre ${ }^{17)}$ (以下 GRDC とする）によ る日流量データを用いて TE+CaMa による河川流量の検 証を 2008 年から 2012 年において 1 年以上観測值がある 点について行った. 図-2a, b にそれぞれの観測地点につ いての相関係数と RMSE を示す. 北アメリカやヨー ロッパの河口付近では相関係数が高く，上流では相関係 数が低くなる傾向がある. 集水面積が広いほど降水の空 間的・時間的に急激な変化の影響が鈍らされるため, 結 果的に流量の再現性が高くなることを示していると考え られる．また，上流になるほどディジタル河川網の表現 による誤差が相対的に大きいことも理由として挙げられ るほか，観測誤差の影響もあると考えられる. 本システ ムにより出力される河川流量は貯水池操作などの人間活 動が考慮されていないため, それによる誤差も存在する と考えられる.

2008 年から 2012 年の間で 1 年分以上データがあり, かつ集水面積が $1,000,000 \mathrm{~km}^{2}$ 以上ある河川の最も上流面 積が大きい観測地点における GRDC, Today’s Earth, $\mathrm{TE}+\mathrm{CaMa}$ の河川流量の日変動を図-3 に示す。CaMaFlood を導入することにより図-3に示されている9つの
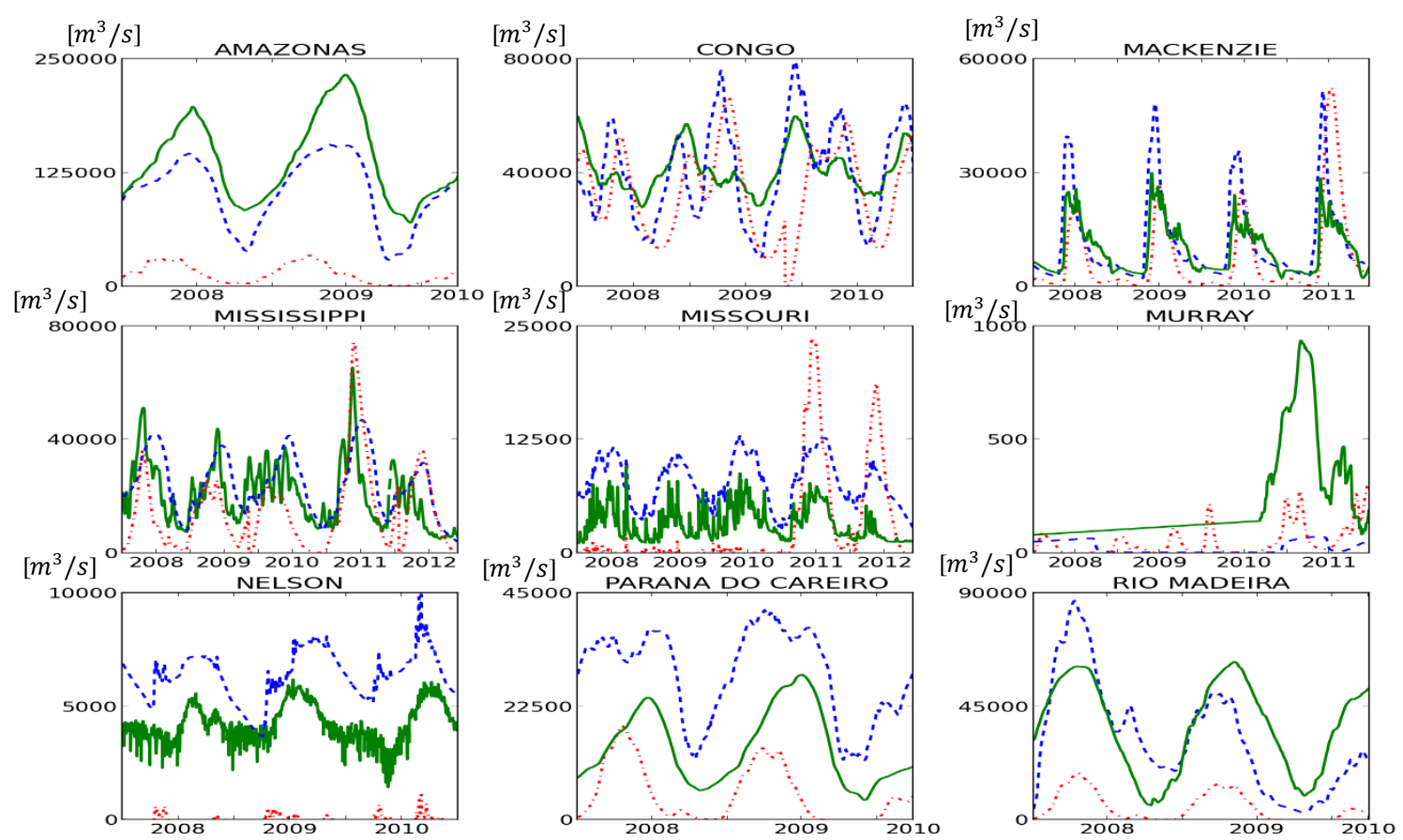

図-3９つの河川についての河川日流量．緑の実線は GRDCによる観測值，青い点線は TE+CaMa 赤い一点鎖線は Today’ s Earthにより算出されたものを示す 


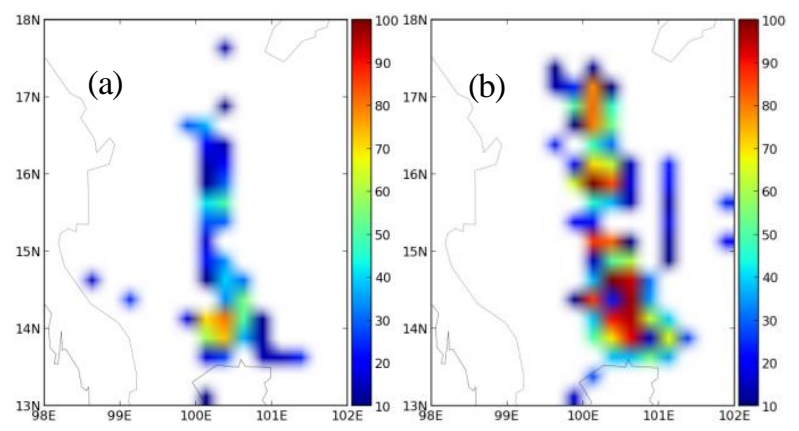

図-4 2011 年 10 月 21 日から 10 月 30 日におけるチャオプラ ヤ流域の氾濫面積割合（a)MODISによるデータ，(b) モ デル出力値

\section{（3）氾濫面積}

本システムによって計算される汇濫面積割合につい て MODIS (Moderate-Resolution Imaging Spectroradiometer) によるデータを用いてタイ王国の中央部を流れるチャオ プラヤ流域についての検証を行った。 ここで，氾濫面積 割合は単位集水面積に対する氾監面積の割合のことであ る．検証に用いる MODIS によるデータは解像度 $500 \mathrm{~m}$ 格子のデータのうち水のスペクトルを検出することに よって冠水域であるピクセルを抽出し ${ }^{18)}$ ，それらを 0.25 度格子のグリッドにおける汇濫面積割合へと変換さ れたものである。

図-4 は 2011 年にチャオプラヤ川流域で洪水が起こつ ていた 10 月 21 日から 10 月 30 日における汇濫面積割合 の比較である. MODIS は通常 10 日間のデータを用い ているため，モデル出力值としては同期間の平均值を用 いた. 図-4a が MODIS による衛星データであり, 図$4 b$ がモデルにより出力されたものである. モデル出力 值では洪水が過大評価される傾向にある。 これの一つの 原因として，先述のとおり本システムではダムが考慮さ れていないことが挙げられる。 また，CaMa-Flood では 各グリッドにおける上流流出量を用いて河道幅や河道深 が経験式で定められているため，河道幅の観測值などを 用いたチューニングを行うことにより精度向上が図られ る. 図-4b はチャオプラヤ川についてチューニングを 行った後の計算結果だが，ピークのタイミングや起伏の 形状を重視したため，さらに詳細なチューニングが必要 である.

\section{（4）影響人口}

洪水による被害の深刻さの一つの指標としてどの程度 の人口が影響を受けるかが挙げられる。 そこでグリッド 単位の人口データを用いて汇濫による影響人口の算定を 行った． 毎年ある程度の洪水が起こっている地域ではな んらかの対策が行われているため，例年と同程度の汇濫 では深刻な影響を受けないと想定される。これを考慮し て，汇濫面積割合の月平年值からの差を各グリッドの影 響人口の割合と仮定する.グリッド毎の人口データ

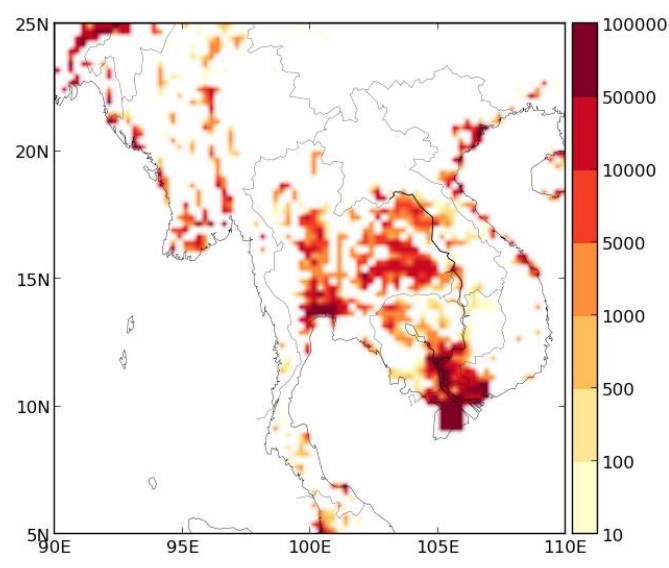

図-5２011年10月25日における影響人口 (チャオプラヤ川流域周辺)
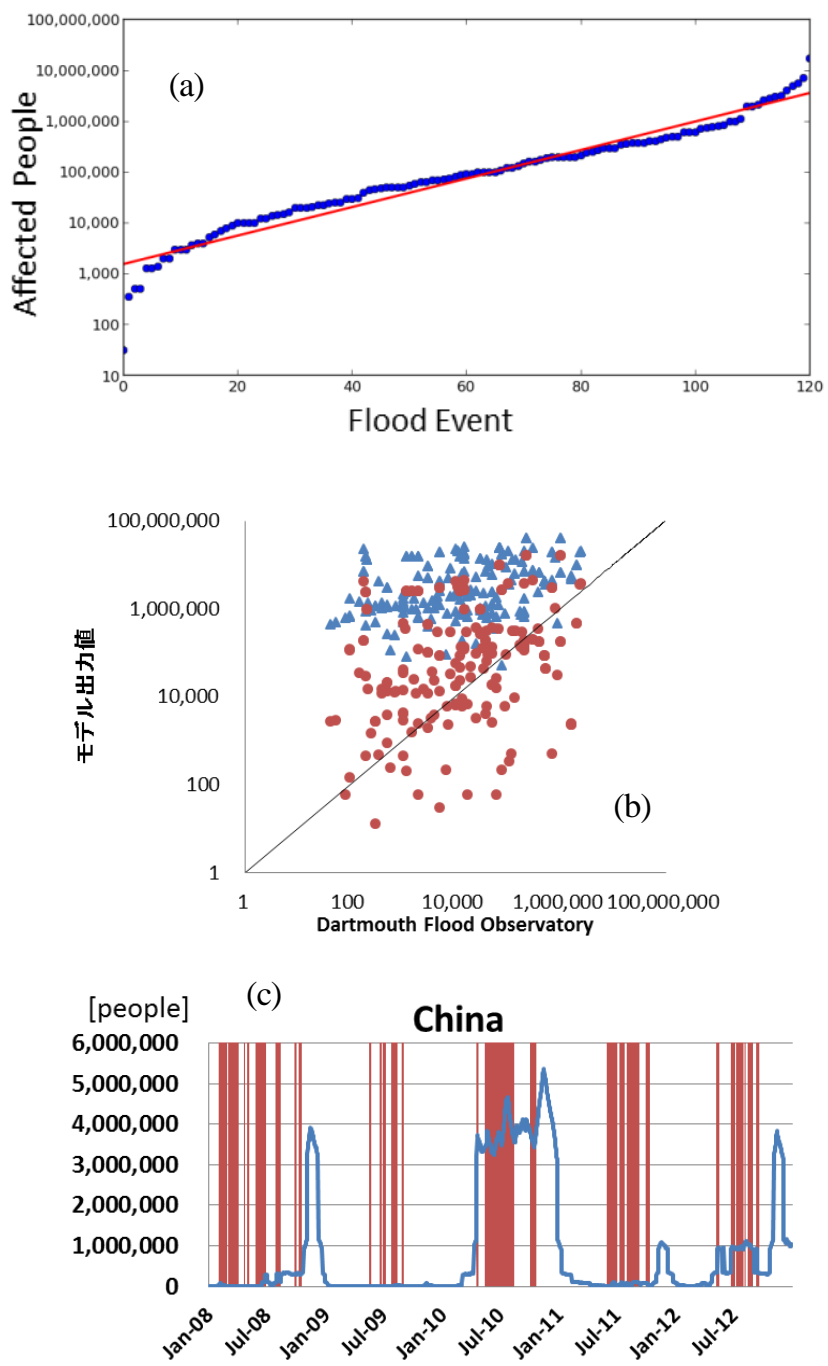

図-6 （a）中国における較正曲線の例 $\quad$ (b) 洪水イベント毎の DFO の登録値とモデル出力值の比較（三角 : 変換前, 丸 : 変換後），(c)中国における本システムによる影響 人口の算定值の時系列変化 (青線) と洪水イベント (赤く塗られている期間) の比較 
は解像度が 0.5 度格子のもの ${ }^{19}$ を本システムの出力值の 解像度である 0.25 度へと変換した. 図-5 は 2011 年 10 月 25 日におけるチャオプラヤ川流域周辺について算定 された影響人口の図である.

上記のようなグリッド毎の影響人口算定には多くの不 確実性がある。しかしながら，洪水の記録が国単位でし か存在せずグリッド単位での影響人口の検証が極めて困 難であることにより，不確実性の定量化がほぼ不可能と なってしまっている，そのため，本システムにより算定 されるグリッド単位の影響人口の意義は社会に対する相 対的なリスクを提示するものが主となるが，現時点で可 能な限り客観的手法に基づいて行った定量的な検証手法 とその結果について以下に記述する.

国単位でDartmouth Flood Observatory ${ }^{20)}$ (以下DFOとす る)に登録されている各洪水イベントの影響人口につい て検証を行う。上記のように月平年值からの差を影響人 口の割合とする単純な仮定では大幅な過大評価が行われ るため, 何らかの変換が必要となる. 本研究の対象期間 外である1985年から2000年における各国の洪水デー夕を 用いる. これらのデータにより各国における洪水の影響 人口についての傾向を表す曲線が得られる. 図-6aに 2008年から2012年において特に洪水が多かった中国の較 正曲線の例を示す．1985年から2000年に起きた洪水によ る影響人口を少ない順に並べ（青点），それにより得ら れる一次回帰曲線（赤線）を用いて影響人口の時系列変 化の変換を行う，検証データとして用いるDFOに登録さ れている洪水に関するデータは国単位であるため, 洪水 イベント毎の検証については国単位における合計值を用 いる. 図-6b, cが変換を行った影響人口の結果の一部で ある. 図-6bは洪水イベント毎の登録值とモデル出力值 の比較である (三角 : 変換前, 丸 : 変換後)。図-6cは中国 について計算された影響人口の日変動である．青線が影 響人口の日変動であり，赤く塗られている期間がDFOに より洪水が起こっていると登録されていた期間である. 図-6bより過去の洪水データを用いて変換を行うことに より，洪水イベント毎に算定される影響人口の精度が上 がっていることがわかる，また，図-6cより洪水が起 こっている期間中にモデルにより算出される影響人口が 増加する傾向があることが分かり，洪水発生を検知する ことが可能であると考えられる.

\section{4. 実時間算定}

本システムのひとつの要素として実時間算定が挙げら れる.X日00時に算出されたGSM-GPVを用いる場合はX 日から2日後まで，X日12時に算出されたGSM-GPVを用 いる場合はX日の1日後から 3 日後までの算定が行われる。 これによって約 2 日前から洪水を検知寸ることが可能と なる.

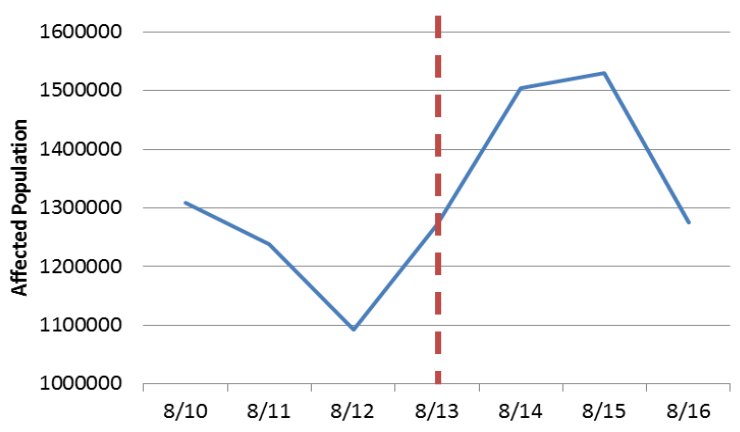

図-7 2013年8月10日から8月16日までのフィリピンにおける影 響人口の時系列変化

図-7にフィリピンにおける2013年8月10日から8月16日 までの影響人口の時系列変化を示す. フィリピンのマニ ラでは豪雨により8月13日から8月21日までマニラで洪水 が発生し,28万人が影響を受けたとされている. 図-7に 示されている結果はそれぞれ3日前の12時に算出された 予測值である.洪水発生の13日に向けて影響人口が増加 し始めていることから洪水の検知に成功していると考え られる. 2013年に起こったマニラ以外の洪水について検 証したところ，2日前の予測值から氾濫面積割合や影響 人口の増加がみられる場合が多く, ある程度の洪水の検 知を行うことは可能であると考えられる.

\section{5. まとめ}

本研究では洪水影響人口の全球実時間算定を行った. 陸面水文過程を実時間で算定するシステムである Today's Earthに河川氾濫モデルCaMa-Floodを導入するこ とにより上記の目的を実現することとした．これにより， 従来の河川モデルではできなかった汇濫原の物理的表現 や高解像度化が可能となった．現段階では1日2回84時間 先までの日単位の予測が行われ，汇濫面積割合・河川流 量・影響人口が主な推計指標となっている。これらを観 測值と比較することにより空振りなど精度に課題は残る ものの，概水洪水の検知アルゴリズムが適正に作動して いることが分かった.

影響人口は汇濫面積を用いて算定された。平年值から の差とグリッド毎の人口データを掛け合わせたものを影 響人口とした．影響人口に関しては過大評価が顕著で あったため, 国単位の過去の被害データを用いて求めた 較正曲線により変換を行い, 過大評価の緩和を図った. 変換を行うことにより国単位の洪水影響人口の精度は上 がり，また，洪水が起こっている期間に影響人口が増加 寸る傾向より洪水の検知が行えていると考えられる.

さらに, 本研究を用いて2013年に起こった洪水の検知 精度を確かめたところ, 約 2 日前には洪水が発生する傾 向を見ることができ，さらなる精度向上により洪水の短 期予測・警報に役立つと考えられる．また，全球実時間 
での評価にさらされることにより，ほぼ常に世界のどこ かで起きている洪水についてシミュレーション精度を確 認することができ, 精度改良へ向けた具体的な経験と知 識が蓄積されると考えられる. 本研究は洪水影響人口の 全球実時間算定システムの基礎が構築された段階にある ため, さらなる検証が必要である. 本システムの大きな 要素である汇濫面積の検証のために，今後衛星センサな どを用いた水面の観測が大いに期待される.

謝辞 : 本研究は科学研究費補助金基盤研究(S)23226012, 文部科学省委託事業気候変動リスク情報創生プログラム, ならびにJST及びJCAによる地球規模課題対応国際科学 技術協力事業(SATREPS/IMPAC-T)の成果の一部です.

\section{参考文献}

1) Komori, D., Nakamura, S., Kiguchi, M., Nishijima, A., Yamazaki D., Suzuki S., Kawasaki, A., Oki, K. and Oki, T.: Characteristics of the 2011 Chao Phraya River flood in Central Thailand, Hydrological Research Letters, Vol.6, pp.41-46, 2012.

2) 第8回被災者支援及び被災地の復旧・復興本部会議. 熊本県, 2013.

3) Ferreira, S., Hamilton K. and Vincent J.R.: Nature, socioeconomics and adaptation to natural disasters: new evidence from floods, Washington D.C. - The World Bank Policy Research working paper, no. WPS 5725, 2011.

4) Intergovernmental Panel on Climate Change (IPCC): Climate Change: The 215 physical science basis. Contribution of Working Group II to the fourth assessment report of the intergovernmental panel on climate change, Cambridge University Press, Cambridge, UK; 976pp, 2007.

5) Pappenberger, F., Dutra, E., Wetterhall, F. and Cloke, H.: Deriving global flood hazard maps of fluvial floods through a physical model cascade, Hydrol. Earth Syst. Sci. Discuss., 9, 6615-6647, 2012.

6) Hirabayashi, Y., Mahendran, R., Koirala, S., Konoshima, L., Yamazaki, D., Watanabe, S., Kim, H. and Kanae, S.: Global flood risk under climate change, Nature Climate Change, 3, 816-821, 2013.

7) Holmes, R.R., Jr. and Wagner, D.M.: Flood of June 11, 2010, in the Upper Little Missouri River watershed, Arkansas, U.S. Geological Survey Scientific Investigations Report 2011-5194, pp.31, 2011.

8) Hashmi, H.N., Siddiqui, Q.T., Ghumman, A.R., Kamal, M.A. and Mughal, H.R.: A critical analysis of 2010 floods in Pakistan, African
Journal of Agricul tural Research, Vol.7(7), pp.1054-1067, 2012.

9) International Federation of Red Cross and Red Crescent Societies (IFRC): World Disasters Report : Focus on information in disasters, Eurospan, 246pp., 2005.

10) Yoshimura, K. and Oki, T.: Today's series contribution to PUB: Value-added water cycle information including flood risk prediction, PUB Newsletter, 2.3, 2007.

11) GPV Data Archive, http://gpv.tkl.iis.u-tokkyo.ac.jp/GPV

12) Takata, K., Emori, S. and Watanabe, T.: Development of the minimal advanced treatments of surface interaction and runoff, Glob. Planet. Change, 38, 209-222, 2003.

13) Yoshimura, K., Miyazaki, S., Kanae, S. and Oki, T.: IsoMATSIRO, a land surface model that incorporates stable water isotopes, Glob. Planet. Change, 51, 90-107, 2006.

14) Oki, T. and Sud, Y.C.: Design of Total Runoff Integrating Pathways (TRIP) - A global river channel network, Earth Interactions, 2, 1998.

15) Yamazaki, D., Kanae, S., Kim, H. and Oki, T.: A physically based description of floodplain inundation dynamics in a global river routing model, Water Resources Research, 47, W04501, 10.1029/2010WR009726, 2011.

16) Adler, R.F., Huffman, G.J., Chang, A., Ferraro, R., Xie, P., Janowiak, J., Rudolf, B., Schneider, U., Curtis, S., Bolvin, D., Gruber, A., Susskind, J., Arkin, P. and Nelkin, E.: The Version 2 Global Precipitation Climatology Project (GPCP) Monthly Precipitation Analysis (1979-Present), J. Hydrometeor., 4, 11471167, 2003.

17) Global Runoff Data Centre, http://www.bafg.de/cln_030 /nn_299766/GRDC/EN/Home/homepage_node.html?_nnn=true

18）澤田義人, 沖一雄, 遠藤貴宏, 沢田治雄：MODISデータ を利用した広域洪水自動監視システムの開発, 生研研 究, 65(4),601-611,2013.

19) 木口雅司, 山崎大, 沖大幹, 渡部哲史, 平林由希子, Shen, Y.: 将来社会経済シナリオALPSを用いた気候変動下におけ る水ストレス影響評価, 水文・水資源学会2012年度研究発表 会要旨集, 258-259, 2012.

20) Brakenridge, G.R.: Global Active Archive of Large Flood Events, Dartmouth Flood Observatory, University of Colorado, http://floodobservatory.colorado.edu/Archives/index.html.

(2013. 9. 30受付) 